\title{
Information Technology as an Enabler of Business Processes Designing During Macroeconomic Transformation
}

\author{
Marius Janson ${ }^{1}$ and Stanislow Wrycza ${ }^{2}$ \\ ${ }^{1}$ Department of Information Systems, University of Missouri-St. Louis, 8001 Natural Bridge Road, St. Louis, \\ MO 63121, U.S.A., mjanson@umslvma.umsl.edu \\ ${ }^{2}$ Department of Information Systems, University of Gdansk, Ul. Armii Krajowej 119/121, 81-824 Sopot, \\ Poland, ekosw@halina.univ.gda.pl
}

\begin{abstract}
The influence of information technology (IT) and market opportunities on business processes reengineering (BPR) and later designing in small firms in course of macroeconomic transformation is explored and reported in this paper. The exploratory, qualitative research method was used to analyse and clarify a data structure. Seven small Polish firms were selected for the survey as a convenience sample. The companies show the use of technology ranging from the standard to advanced one. In the result of research process, the model of new business processes design is proposed. It is based on the idea of the combined IT initiative/Market demand BPR enabler. The model was constructed and then verified by means of exploring, analysing and generalising data acquired in the interviewed companies, and synthesised in tabular form in the paper.
\end{abstract}

Keywords. Information technology (IT), business processes reengineering (BPR), small firm, macroeconomic transformation, BPR enabler, exploratory qualitative research method.

\section{Introduction}

Information technology (IT) is an essential component of a firm? s strategy in a global market (Ives, et al., 1993). Hence, it is not surprising that academics and practitioners have focused on identifying key IT issues, first in Western Industrialised Countries (Dickson, et al., 1984; Hirschheim, 1988; Niederman, et al., 1991; Watson, 1989; Watson and Brancheau, 1991) world and subsequently also in Eastern European countries (Dekleva, and Zupancic, 1992; Wrycza, and Plata-Przechlewski, 1994).

The above mentioned surveys described the views, problems, opinions, and threatens of Central European managers and IT professionals at the beginning of macroeconomics transformation in this region. The Central European countries are now rather at the end of transition process, functioning mostly in the conditions of market economy. This situation evokes new questions. What is the influence of the information technology on business expansion, especially in a new private sector? What is the level of the acceptance and adoption of the current important and prospective IT solutions and initiatives in this region? Does the IT stimulate to start the new business processes and firms? What type? Or do the Central Europeans give their own original contribution to IT/IS modern development? It seems that the above and similar questions need more in-depth analysis. Therefore we have applied the exploratory qualitative interview-based method to answer the questions and explore the strategic IT/business liaison in this region. We have selected seven small firms in Poland - the country with the longest economic transformation and market economy experience in Central Europe. 
The paper starts with Introduction. In the second chapter the principles of the selected exploratory, qualitative, interview-based research method as well as the convenience sample are described. Net, the evolution of small business sector in Poland is presented. The main finding of the research concerning the relationships between IT and business processes enabling and designing as well as their model are comprised in part four. The paper is finalised with concluding remarks.

\section{Research Method and Convenience Sample}

Our project is a qualitative interview-based attempt at uncovering and making explicit the conditions and individual actions surrounding the creation and development of entrepreneurial initiatives in Poland. Hartwick et al. (1994) elaborated the different objectives of confirmatory and exploratory research approaches. Confirmatory research seeks support for hypotheses which have been formulated using a priori theory. These hypotheses are subsequently tested using data from carefully controlled experimental studies.

Exploratory research proceeds differently than confirmatory studies - rather than relying on large randomly selected samples, exploratory analysis employs probability distribution, exploratory analysis for the most part uses tabular and graphical data displays and other techniques for probing the data flexibly (McNeil, 1977). Exploratory analysis represents a first contact with the data and aims to isolate data patterns and features, and to uncover, clarify, and simplify a data structure (Velleman et al., 1981). The data acquire meaning within the analyst? s frame of reference, because he or she searches for a satisfactory structure by confronting the data with a variety of alternative models (which is to say: the model follows the data). In this spirit exploratory data analysis is defined by Benzecri (1980) as a ? method that extracts structure from data? .

Before scheduling a series of interviews with entrepreneurial talents in Poland we first fixed our projects goals. The semi-structured interview sought information on the: 1) age of the business and changing business conditions resulting from the demise of ancient regime, 2) number of partners and type of company's managerial structure, 3) number of employees and their contribution to achieving company objectives, 4) nature of the business and competition, and current and future markets, 5) business clients and the services delivered, 6) company's operating philosophy, 7) the company's use of IT to: a) serve the client, b) manage and run the company, c) manage and maintain the company? s information systems, and d) the company? $\mathrm{s}$ use and acquisition of standard as well as special software and hardware (e.g., wordprocessing, spreadsheet, and data base), and 8) the balance between providing clients a quality product or service, workers meaningful work, realising adequate returns on investment, and staying ahead of the competition. The detailed descriptions of the survey and the extensive tabular comparisons of the results are presented in Janson and Wrycza (1996).

We interviewed seven small business firms in Gdansk area, selected randomly. Gdansk agglomeration is one of the fastest economically growing regions in Poland. The excerpt of the survey is shown in Table 1 (particularly quantitative data). All interviews except one, were conducted in English. Despite their stark exteriors, office buildings were always pleasantly arranged inside. All seven companies had made considerable investments in personal computers, office furniture, stationary, binders and boxes. Employees were professional, polite, patient and did not interrupt. The majority of employees understand and speak English well. Furthermore, employees displayed team spirit which, we suspect, arose from a flat hierarchical management structure. 
Employees had great freedom to arrange their own activities and they shared the professionalism of their employers; they took care of their outward appearance, dress and they were dedicated to their organisation. Five of the seven use English names. The two exceptions are organisations which were active before 1989 and have Polish names "Doradca" (Advisor) and "Kancelaria Notarialna" (Notary Public).

By using an English name the company makes explicit its intention to be active internationally. One interviewee explained that firms prefer English names because it makes it easier for their international partners and customers who would have a hard time pronouncing the strings of consonants that occur in many Polish names. Not everyone is pleased that Polish firms have English names and the practice is at times criticised in the media.

\begin{tabular}{|c|c|c|c|c|c|}
\hline Firm & $\begin{array}{l}\text { Business } \\
\text { Start }\end{array}$ & $\begin{array}{l}\text { Number } \\
\text { of } \\
\text { partners }\end{array}$ & $\begin{array}{l}\text { Number } \\
\text { of employees }\end{array}$ & $\begin{array}{l}\text { Number or type of } \\
\text { clients }\end{array}$ & Business nature \\
\hline $\begin{array}{l}\text { English } \\
\text { Language } \\
\text { School }\end{array}$ & 1989 & 4 & 15 & 1000/year & $\begin{array}{l}\text {-High quality English } \\
\text { Education }\end{array}$ \\
\hline $\begin{array}{l}\text { Young } \\
\text { Digital } \\
\text { Poland }\end{array}$ & 1989 & 4 & $\begin{array}{l}11 \text { (high-tech } \\
\text { education and } \\
\text { experience }\end{array}$ & Over 1000 & $\begin{array}{l}\text {-Acoustical } \\
\text { Instrumentation } \\
\text { •Multimedia Software }\end{array}$ \\
\hline Doradca & 1985 & 15 & 30 & $\begin{array}{l}\text { State-owned firms, } \\
\text { cooperatives, } \\
\text { independent firms }\end{array}$ & $\begin{array}{l}\text {-Consulting services, } \\
\text {-Privatisation, } \\
\text {-Financial Marketing, } \\
\text {-Valuation }\end{array}$ \\
\hline Combi Data & 1992 & 3 & $15-20$ & $\begin{array}{l}150 \text { students, } \\
\text { City Hall, } \\
\text { Emergency Management }\end{array}$ & $\begin{array}{l}\bullet \text { End-user education, } \\
\text { •GIS Systems, } \\
\bullet \text { Emergency Information } \\
\text { Systems }\end{array}$ \\
\hline $\begin{array}{l}\text { Kancelaria } \\
\text { Notarialna }\end{array}$ & $\begin{array}{l}\text { Till 1989- } \\
\text { state-owned } \\
\text { 1991- } \\
\text { reprivatized }\end{array}$ & 3 & 6 & Individuals, Companies & Legal Services \\
\hline $\mathrm{DC}$ & 1989 & 3 & 28 & Individuals, Companies & $\begin{array}{l}\text {-Software and Computer } \\
\text { Selling, } \\
\text {-University Software } \\
\text { Development } \\
\text {-Insurance Software, } \\
\text {-End-User Education }\end{array}$ \\
\hline $\begin{array}{l}\text { Cross/ } \\
\text { Comm }\end{array}$ & 1991 & 2 & 150 & 150 Companies & $\begin{array}{l}\text {-Routers Software } \\
\text { Development, } \\
\text {-Networks (LANS and } \\
\text { WANS) installation and } \\
\text { services }\end{array}$ \\
\hline
\end{tabular}

Table 1: The Convenience Sample Characteristics 


\section{Small Business Development in Poland}

Prosperity in and political independence of Poland depend on the nation's successful transformation from a command to a free market economy. Economic transformation imposes excruciatingly difficult economic conditions on the populace. The future of Poland is far from certain and if economic transformation were to stall, the nation may be pushed into the grey sphere of economic stagnation. Information is a key to successful economic transformation.

During the interwar (1918 - 1939) years private companies in Poland were the rule rather than the exception. In the 1940s nationalisation of factories, real estate, and land commenced. However, small farms were allowed to exist as well as some small shops and handicrafts. During the 1980s there was some growth in the numbers of small firms that provided services. These were mostly organisations at the periphery of the national economy such as, for example, small farmers, shops, handicrafts, or consulting firms such as Doradca. With the demise of the ancient regime in 1989 the private sector has experienced substantial growth. As shown in Table 2, the percentage of employment has shifted away from the public toward the private sector. Whereas in 1990 the private sector counted for less than 50\% of the nation employment, in 1994 this figure had increased to over $60 \%$.

Despite their precarious legal status businesses that survived the period before 1989 started the process of economic transformation at a surer footing than firms which were formed during the early 1990s.

\begin{tabular}{|l|l|l|l|}
\hline Year & Employment (Thousand) & Public Sector (Percent) & Private Sector (Percent) \\
\hline 1990 & 16,145 & 51.1 & 48.9 \\
\hline 1991 & 15,443 & 45.7 & 54.3 \\
\hline 1992 & 15,011 & 44.0 & 56.0 \\
\hline 1993 & 14,761 & 41.1 & 58.9 \\
\hline 1994 & 14,923 & 39.0 & 61.0 \\
\hline
\end{tabular}

Table 2. Employment in the Public and Private Business Sectors in Poland

The older organisations were better prepared legally and had more business experience upon which to build future growth. Also, during their infancy the pre 1990's firms had fewer competitors and did not have to invest immediately large sums of money in information technology. Hence, these older firms were better prepared than their younger counterparts to face the harsh economic realities such as the decrepit telecommunications system. In fact, even today the way around telecommunication's problem is to sign up on the INTERNET or to acquire bandwidth on a satellite service. This is precisely what two of the seven companies have done: Young Digital Poland is on the Internet while Cross Comm has access to a satellite system. However, these are high cost solutions to problems brought about by a poor telecommunication infrastructure, which few companies can afford.

\section{Business Process Reengineering or Business Process Inventing}

BPR - Business Processes Reengineering focuses the attention of many researchers and practitioners in the field of information systems development. The investigation carried out by us confirms that BPR is extensively practiced in Polish firms being in the process of transformation. Hammer and Champy (1993) define reengineering as "the fundamental rethinking and radical redesign of business processes to achieve dramatic improvements in critical contemporary measures of performance such as cost, quality, service and speed". Yes, the macroeconomic transformation, which took place in Poland and later in the other Central 
and eastern European countries at the beginning of nineties, was fundamental, radical, dramatic and critical.

It created a wide free space for individual and corporate activities for people with the entrepreneurial spirit and readiness to accept the tough rules of free market economy. As a matter of fact, it was the free space needed for BPR accomplishment in the business, microeconomic scale. Business processes were enforced or rather introduced in a natural way (by the way - without knowing the BPR theory) by global transformation of economic system.

There have been two sphere of BPR application:

a) in the public sector, in big firms, employing several thousands workers it was classical BPR just to survive, reconstruct, compete effectively and finally expand the market,

b) in the private sector, practically in small business, in over three million new companies, which started from the scratch - it was what we call business processes inventing or at least initiating.

These before non-existent firms have had to find their way to function in free market economic conditions.

The research concentrated around the second sphere taking into account its uniqueness. It is, of course, an extreme example but compliant with the general BPR definition. In particular we have tried to explore the influence of information technology and systems on new business processes design and later on the performance in small firms. Therefore, according the exploratory research method where model follows data we probed data flexibly and confronted them with different alternative models. The closest description was connected with the Davenport's (1993) model:

IT Initiative----------------? Process Change------------------? Economic Outcome

It proved very quickly that PC technology is not the IT stimulus or innovator we are looking for. Practically all small firms, starting from a one-man travel office are equipped with PCs, and peripherals.

Staff is effective in using and operating PC systems, wordprocessors, spreadsheets, databases and bookkeeping systems. They are simply a "must", a standard for small business. An advantage of starting late?

Analysing and comparing different cases we came into some general regularities observed in the successful firms. It seems that their IT-Process-Productivity relationship is like on the figure 1. There are two process enablers which are strictly connected and act parallel. The combination of IT technology and the market niche is the initiator of the business processes establishment and development. They interact in a new process initiating and designing. A newly designed process means very often also a new small company. Two initiators of the new process invention play the role of "technology push" and "market pull" respectively. A country's economic and technological level as well as the foreign trade challenges determine the opportunities and threats for newly invented and implemented ideas. 


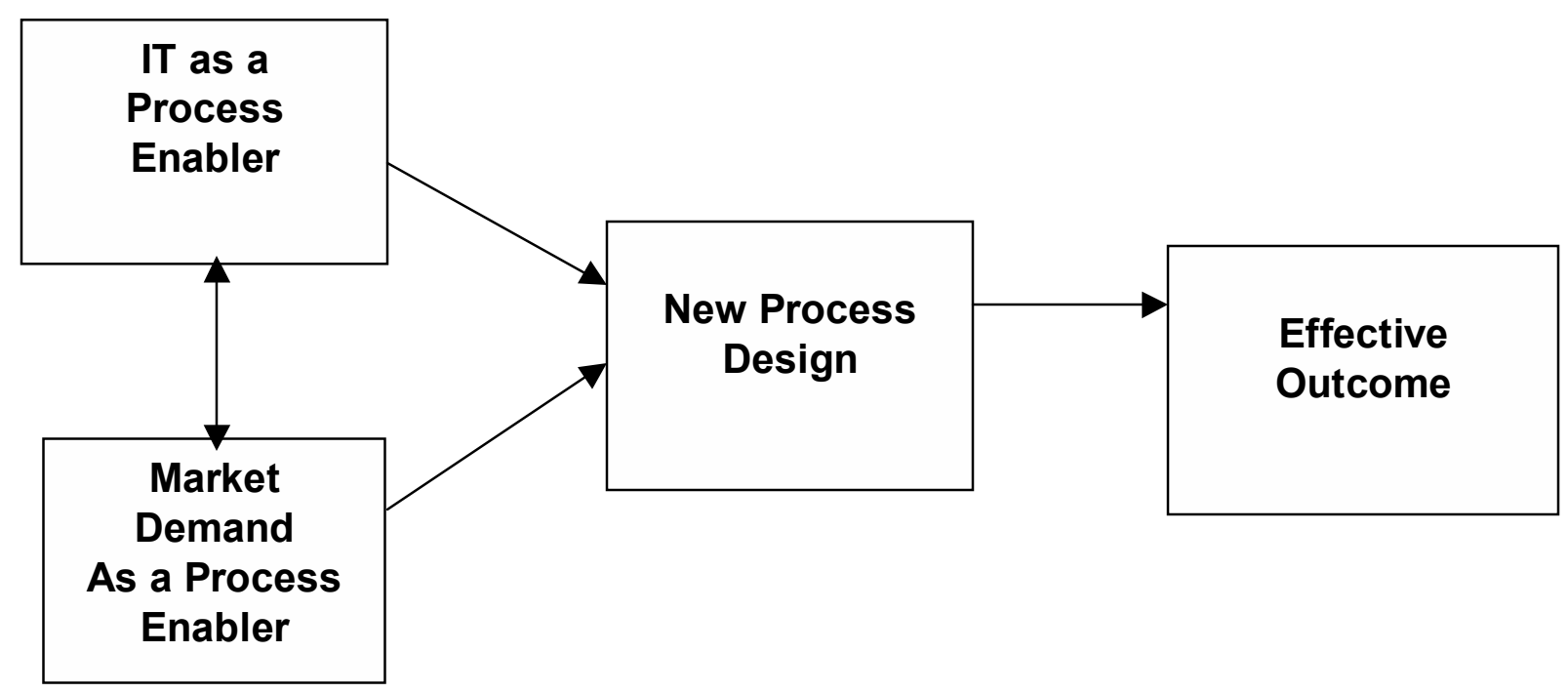

Figure 1: Business Processes Initiating and Designing

There are technological achievements not accepted by the market which maybe too narrow or not prepared. The cases of bankruptcy or stagnation are still frequent. However, if the firm or the buisness process is successful than the final positive outcome can be considered in the respect of the firm development and in a broader macroeconomic context advantage.

Our findings in using the paradigm (Figure 1) for exploring the problem with respect of the selectd small buisness firms are synthesised in table 3 .

When looking at the IT initiatives for starting the process invention and designing, it is visible that very up-to-date solutuions and technologies are used, for example satellite transmission, multimedia technology, different sorts of computer networking, and business applications of INTERNET. On the other hand, market opportunities imply services and production for foreign partners, resulting in reductuion of underinvestments and delays in certain sectors of business and social life, by coping with the challenges of new technological developments and cultural standards. There is a whole range of visions and than designs of new proceses invoked by the two basic combined stimuli. They include modern private educaiton on different levels, development of multimedia and network software, information systems for emergency managing. Some of the firms concentrate only on one process, while others are taking on new opportunities, developing several streams of versatile processes. For example, CombiData except emergency management analysed in table 3, develops geographical information systems using SUN workstations, runs a professional school for computer network specialists, and offers outsourcing for management information systems. The effective outcomes are prodcuts and services strictly connected with the innovative processes. It is worth to stress that managerial focus of new firms is on hight ethnical or quality standards. This network software is compliant with ISO 9001 standards, accountancy with Western-style, language courses with Oxford University schemes. The success of these outcomes is the verification of the correctness of the new processes design. 


\begin{tabular}{|c|c|c|c|c|}
\hline Name of firm & $\begin{array}{l}\text { IT Enabler } \\
\text { (Technology } \\
\text { Push) }\end{array}$ & $\begin{array}{l}\text { Economic or Social Market } \\
\text { Demand Enabler }\end{array}$ & New Process Design & Effective Outcome \\
\hline $\begin{array}{l}\text { English } \\
\text { Language } \\
\text { Services }\end{array}$ & $\begin{array}{l}\text { CD Rom, } \\
\text { Interactive Video }\end{array}$ & $\begin{array}{l}\text { Opening of foreign trade (state- } \\
\text { licensed till 90ties) to all - public } \\
\text { and private companies }\end{array}$ & $\begin{array}{l}\text { Modern, effective, competitive teaching of } \\
\text { businessmen and managers aiming at or } \\
\text { involved in foreign trade activities with } \\
\text { English grades recognised internationally }\end{array}$ & $\begin{array}{l}\text { High quality education business in using } \\
\text { modern method technologies and staff } \\
\text { (Polish, British) }\end{array}$ \\
\hline $\begin{array}{l}\text { Young } \\
\text { Digital } \\
\text { Poland }\end{array}$ & $\begin{array}{l}\text { Multimedia } \\
\text { technology, } \\
\text { Business } \\
\text { applications of } \\
\text { the Internet }\end{array}$ & $\begin{array}{l}\text { The growing significance of } \\
\text { multimedia technology and its } \\
\text { share of educational aids market } \\
\text { in Western industrialised } \\
\text { countries } \\
\text { Well skilled Polish professionals } \\
\text { in multimedia technology }\end{array}$ & $\begin{array}{l}\text { Development of multimedia software and } \\
\text { multimedia products, marketing and selling } \\
\text { them on the markets of Western industrialised } \\
\text { countries }\end{array}$ & $\begin{array}{l}\text { Multimedia software and CD-ROM } \\
\text { procucts } \\
\text { Multimedia laboratory for product } \\
\text { development } \\
\text { Managmeent and staff coping with up-to- } \\
\text { date technology, developing it and } \\
\text { competing on foreign advanced markets }\end{array}$ \\
\hline Doradca & $\begin{array}{l}\text { LANs, } \\
\text { Accounting } \\
\text { information } \\
\text { systems }\end{array}$ & $\begin{array}{l}\text { Shift and adoption into Western } \\
\text { style of accounting in both public } \\
\text { and private sectors of economy } \\
\text { Privatisation and reprevatisation } \\
\text { globally in economy and firms } \\
\text { Privatisation expertise needed in } \\
\text { the other countries in } \\
\text { transformation, for example in } \\
\text { Russia }\end{array}$ & $\begin{array}{l}\text { Consultation and expertise in up-to-date } \\
\text { accountancy and privatisation of business } \\
\text { Implementation of the Western-style } \\
\text { accounting information systems } \\
\text { Accomplishment of company's privatisation }\end{array}$ & $\begin{array}{l}\text { Widespread acceptance of the Western- } \\
\text { style accountancy and its implementation } \\
\text { in business organisations (in a } \\
\text { computerised version) } \\
\text { Privatisation of firms in Poland and } \\
\text { abroad }\end{array}$ \\
\hline $\begin{array}{l}\text { Combi } \\
\text { Data }\end{array}$ & $\begin{array}{l}\text { Metropolitan } \\
\text { Area Networks, } \\
\text { Cellular Phones }\end{array}$ & $\begin{array}{l}\text { The social demand for quicker } \\
\text { and more reliable emergency } \\
\text { actions in case of accidents }\end{array}$ & $\begin{array}{l}\text { Managing city emergencies involving police, } \\
\text { hospitals, city officers }\end{array}$ & $\begin{array}{l}\text { The effective, reliable emergency } \\
\text { information system }\end{array}$ \\
\hline $\begin{array}{l}\text { Kancelaria } \\
\text { Notarialna }\end{array}$ & $\begin{array}{l}\text { LANs, } \\
\text { Databases, } \\
\text { Legal Information } \\
\text { Systems }\end{array}$ & $\begin{array}{l}\text { The growing number of legal } \\
\text { transactions and operations } \\
\text { particularity in the private sector }\end{array}$ & $\begin{array}{l}\text { Computerisation of legal operations and its } \\
\text { databases }\end{array}$ & $\begin{array}{l}\text { Information system supporting the daily } \\
\text { operations of the legal notary }\end{array}$ \\
\hline $\begin{array}{l}\text { Software } \\
\text { generators, } \\
\text { CASE tools }\end{array}$ & $\begin{array}{l}\text { Software } \\
\text { generators, CASE } \\
\text { tools }\end{array}$ & $\begin{array}{l}\text { Improvement of university } \\
\text { administration fuctioning } \\
\text { New, additional tasks for } \\
\text { university administration }\end{array}$ & $\begin{array}{l}\text { Restructruing the University administration } \\
\text { procedures } \\
\text { Software development to support university } \\
\text { administration }\end{array}$ & $\begin{array}{l}\text { Management information system for } \\
\text { university administraiton, unified for all } \\
\text { universities }\end{array}$ \\
\hline Cross/Comm & $\begin{array}{l}\text { Computer } \\
\text { Networks, } \\
\text { Satellite } \\
\text { transmission, } \\
\text { Acoustical } \\
\text { instruments }\end{array}$ & $\begin{array}{l}\text { The increasing demand for WAN } \\
\text { and LANs in different businesses } \\
\text { and institutions of the country }\end{array}$ & $\begin{array}{l}\text { Computer networks installation, services and } \\
\text { programming }\end{array}$ & $\begin{array}{l}\text { Reliable provider of advanced computer } \\
\text { network services compliant with ISO } \\
9001 \text { certification } \\
\text { Network software for routers }\end{array}$ \\
\hline
\end{tabular}

Table 3. New Processes Design

\section{Conclusions}

The qualitative, explorative method, used in this paper, allowed to explore and then construct the model of business processes design in small firms, starting to operate in the conditions of macroeconomic transformation to free market economy. The empirical data, which extracted into model proved that combination of modern IT initiatives and market opportunities is the basic enabler of the business processes reengineering (BPR) or designing. The data structure was indicated by details of the other elements of the model, i.e. new processes design and effective outcome, gathered in convenience sample 
and presented in Table 3. But besides the model there is a human side of business processes initiating and development in economically transforming countries of Central Europe like Poland. Transforming opportunities into business success requires managers with the insight, flexibility, and decisiveness of the seven partners discussed by our study.

\section{References}

Benzecri, F. (1980) Data Analysis, Paris, France: Dunod

Chalmers, J. (1993) "Survey Telecommunications," Business Central Europe, Vol. 1, No. 1., $35-48$.

Cook, J. (1993) "Fighting Blue Beards: Intellectural Property Pirates Still Roam the Czech Seas," Busines Central Europe, Vol. 3, No. 20, 60.

Davenport, D.H. (1993) "Process Innovation: Reengineering Work Through Information Technology," Harvard Business School Press, Boston

Dekleva, S., and Supancic, J. (1992) "An Empirical Investigation of Key Issues in Information Systems Management," in Proceedings of the Thrid International Converence, Poland: Sopot, Wrycza (ed.), 95-104.

Dexter, A., Janson, M., Kiudorf, E., and Laast-Laas, J. (1993) "Key Information Technology Issues in Estonia," Jornal of Strategic Informaton Systems, Vol. 2, No. 2, 139-152.

Dickson, G., Leitheiser, R., Nechis, M., and Wetherbe, J. (1984) "Key Information Systems Issues for the 1980s," Management Information Systems Quarterly, Vol. 8, No. 3, 135-148.

Frost and Sullivan (July/August, 1995) "Information Technology Special Suppllement: Visgrad Realities, " Business Central Europe, Vol. 3, No. 23, III XVIII.

Hammer M., Champy J. (1993) "Reengineering the Corporation," Harper Business, New York.

Hartwick, J., and Barki, H. (December, 1994) "Hypothesis Testing and Hypothesis Generating Research: An Example from the User Participation Literature," Information Systems Research, Vol. 5, No. 4, 446-449.

Hirschheim, R. (1988)"An Exploraiton Into the Management of the Informaton Systems Fuction: Key Issues and an Evolutionary Model," Proceedings of the Converence on Inforamtion Technology Management for Prodcutivity and Strategic Advantage, Singapore, 4.15-4.38.

Ives, B., Jarvenpaa, S., and Mas, R. (1993) "Global Business Drivers: Aligning Information Technology to Global Business Strategy," International Business Machine Journal, Vol. 32, No. 1, 143-161.

Janson, M., Wrycza, S., (1996) "IT in Small Companies: A Case Study of Business Transformatoin in Poland," (to be published).

McNeil, D.R. (1977) "Interactive Data Analysis: A Practical Primer," New York, NY: Wiley.

Niederman, F., Brancheau, J., and Wehterbe, J. (1991) "Information Systems Managmeent Issues in the 
1990s," Management Inforamtion Systems Quarterly, Vol. 15, No. 4, 475-500.

Pullar-Strecker, T., and Papp, B. (Decmeber 1993/January 1994) "Manager Wanted," Business Central Europe, Vol. 1, No. 7, 7-9.

Velleman, P., and Hoaglin, d.C. (1981) "Applications, Basics, and Computing of Exploratory Data Analysis," Boston, MA: Duxbury Press.

Watson, R.T., (August, 1989) "Key Issues in Inforamtion Systems Management: An Australian Perspective 1988," Australian Computer Journal, Vol. 21, No. 3, 118-129.

Watson, R.T., and Brancheau, J.C. (March, 1991) "Key Issues in Information Systems Management: An International Perspective," Information and Management, Vol. 20, No. 3, 213-223.

Wrycza, S., and Plata-Przechlewski, T. (1994) "key Issues in Information Systems Management: The Case of Poland," in Proceedings of the Fourth International Converence on Information Systems Development, J. Zupancic, and S. Wrycza, (eds.), Bled, Slovenia, 289-296. 